\title{
Beta-lactam resistance in enterobacteria isolated from animal and water
}

\author{
Cicuta, M.E. ${ }^{1}$, Roibón, W.R. ${ }^{1}$; Barceló, M.C..; Arzú, O.R. ${ }^{2}$; Amable, V.I. ${ }^{1}$ \\ Cátedras de Microbiología ${ }^{1}$ y Bromatología ${ }^{2}$, Facultad de Ciencias Veterinarias, Universidad Nacional \\ del Nordeste, Sargento Cabral 2139, Corrientes (3400), Argentina. \\ Tel/Fax 54-379-4425753. E-mail: cicuta@vet.unne.edu.ar
}

\begin{abstract}
Cicuta, M.E.; Roibón, W.R.; Barceló, M.C.; Arzú, O.R.; Amable, V.I.: Beta-lactam resistance in enterobacteria isolated from animal and water. Rev. vet. 25: 1, 3-6, 2014. The susceptibility to $\beta$-lactam antibiotics was analysed in thirty seven strains of enterobacteria from both animals and non-chlorinated water of rural areas from Corrientes, North-eastern Argentina. Twenty nine were isolated from animals: Klebsiella pneumoniae $(\mathrm{n}=9)$, Klebsiella oxytoca $(\mathrm{n}=1)$, Proteus mirabilis $(\mathrm{n}=7)$, Escherichia coli $(\mathrm{n}=12)$, and 8 from non-chlorinated water: $E$. coli $(\mathrm{n}=5), K$. pneumoniae $(\mathrm{n}=2), K$. oxytoca $(\mathrm{n}=1)$. The antibiograms were performed by the Kirby-Bauer technique using antibiotic discs of ampicillin, cefotaxime, cefepime, piperacillin and with $\beta$-lactamases inhibitors: clavulanic acid-amoxicillin, sulbactam-cefoperazone and tazobactam-piperacillin. Carbapenems with an EDTA disc as metallo $\beta$-lactamases inhibitor were also used. Neither phenotypically ESBL (extended-spectrum beta-lactamases) nor carbapenemase were detected. It can be inferred that the resistance observed in this assay may be attributed to a different source.
\end{abstract}

Key words: domestic animals, enterobacteria, antibiotic resistance, $\beta$-lactamases.

\begin{abstract}
Resumen
Cicuta, M.E.; Roibón, W.R.; Barceló, M.C.; Arzú, O.R.; Amable, V.I.: Sensibilidad de enterobacterias de origen animal y agua frente a antibióticos betalactámicos. Rev. vet. 25: 1, 3-6, 2014. Se analizaron 37 cepas de enterobacterias, 29 provenientes de diferentes animales: Klebsiella pneumoniae $(\mathrm{n}=9)$, Klebsiella oxytoca $(\mathrm{n}=1)$, Proteus mirabilis $(\mathrm{n}=7)$, Escherichia coli $(\mathrm{n}=12)$, así como 8 aisladas de aguas no clorinadas de perforaciones, pozos de balde y tanques rurales de diferentes lugares de la Provincia Corrientes (Argentina): $E$. coli $(\mathrm{n}=5), K$. pneumoniae $(\mathrm{n}=2)$ y $K$. oxytoca $(\mathrm{n}=1)$. Con el fin de conocer su sensibilidad a antibióticos $\beta$-lactámicos se realizaron antibiogramas de acuerdo con el método de KirbyBauer. Se utilizaron discos de ampicilina, cefotaxime, cefepime, piperacilina y con el agregado de inhibidores de $\beta$-lactamasas: amoxicilina-clavulánico, cefoperazona-sulbactam y piperacilina-tazobactam. También fueron utilizados carbapenems con un disco de EDTA como inhibidor de metalo $\beta$-lactamasas . No se detectaron fenotípicamente $\beta$-lactamasas de espectro extendido ni carbapenemasa, por lo que se infiere que la resistencia observada se debió a mecanismos de diferente origen.
\end{abstract}

Palabras clave: animales domésticos, enterobacterias, resistencia antibiótica, $\beta$-lactamasas.

\section{INTRODUCTION}

The most common mechanism by which bacteria are resistant to antibiotics is by producing enzymes that inactivate the drugs ${ }^{1}$. $\beta$-lactam antibiotics (penicillins and cephalosporins) can be inactivated by enzymes known as $\beta$-lactamases ${ }^{1,4}$. Hundreds of $\beta$-lactamases have been described; they can be both plasmid or chromosomic encoded, and have varying degrees of activity against the different $\beta$-lactam antibiotics ${ }^{4}$. Many bacteria produce multiple $\beta$-lactamases. In response to

Recibido: 30 octubre 2013 / Aceptado: 19 diciembre 2013 the proliferation and spread of $\beta$-lactamases, the pharmaceutical industry has developed some $\beta$-lactam antibiotics that are more resistant to hydrolysis by these enzymes ${ }^{2}$. In addition, some combination drugs have been produced which contain both a $\beta$-lactam antibiotic and a $\beta$-lactamase inhibitor; the inhibitor has high affinity for the $\beta$-lactamase enzyme, irreversibly binds to it, and thereby preserves the activity of the $\beta$-lactam antibiotic ${ }^{10}$. About one-tenth of isolates of gram-negative pathogens seem to produce extended-spectrum beta-lactamases $(\mathrm{ESBL}){ }^{18}$.

The phenotipic detection of ESBL are based in the inhibition of the majority of these enzymes by cla- 
vulanic acid and the utilization of $3^{\circ}$ and $4^{\circ}$ generation cephalosporins and aztreonam as indicators ${ }^{18}$. The double disc synergy proof consist to situate a clavulanic-amoxicillin disc next to $\beta$-lactam antibiotic discs as indicators. The ESBL production is demonstrated by enlarging the inhibition halo of any indicator by the clavulanic acid action. The discs with inhibitors is one of the recommended methods of the Clinical Laboratory and Standards Institute $^{3}$. This method consists in comparing a $3^{\circ}$ or $4^{\circ}$ generation cephalosporin-inhibition zone alone or with clavulanic acid. The activity increase of cephalosporin in presence of clavulanic acid indicates ESBL production. ESBL genes are frequently in the same plasmids that codifies aminoglucosid and sulfonamide resistance. Some enterobacteria species posses changes that add quinolone resistance so that means multiresistance ${ }^{10}$.

A mechanism founded in some species naturally transformed, had been described as $\beta$-lactam resistant, where penicillin binding proteins (PBP) were altered, presumably by transformation, with reduced affinity to $\beta$-lactam antibiotics $7,15,16$. The resistance to these, in the majority of Gram negative species and some Gram positive, is due to the presence of a $\beta$-lactamase, which modifies the antibiotic, avoiding its fixation to PBPs ${ }^{18}$. Drug efflux systems, pump out a broad range of chemically and structurally unrelated compounds from bacteria, in an energy-dependent manner, without drug alteration or degradation ${ }^{13}$. Although drug efflux pumps are found in Gram-negative and Gram-positive bacteria, efflux mediated resistance in Gram-negative bacteria is a more complex problem due to the molecular architecture of the cell envelope ${ }^{6,9}$. As a consequence, drug resistance in many cases is attributable to synergy between reduced drug intake (mainly due to low outer membrane permeability) and active drug export (via efflux pumps) ${ }^{11}$.

Along with the steady increase of nosocomial infection rates in veterinary clinics, particular attention has recently been drawn to the genetic background of multi-resistant strains, resulting in the identification of certain genetic lineages which frequently appear in both, human and animal samples: extended-spectrum $\beta$-lactamases (ESBL)-producing Enterobacteriaceae ${ }^{14}$. These sequence types (ST), include the pandemic ST131 for ESBL-producing E. coli ${ }^{18}$.

The isolation of opportunistic Proteus mirabilis and Proteus vulgaris is very frequent in clinical samples from canine otitis at the Bacteriologic and Mycologic Diagnostic Laboratory of the Microbiology Area of the Veterinary Science Unit at National North East University of Corrientes, Argentina. In eight years (from 2006 to present) over 339 pathological samples, in $69(20,3 \%)$ enterobacteria were isolated, from these,
Table 1. Detail of 29 strains of Enterobacteria of animal origin.

\begin{tabular}{|c|c|c|}
\hline $\mathrm{N}^{\circ}$ bacterial strain & origin & reference \\
\hline 1 Klebsiella pneumoniae & canine otitis & Ex O 1031 \\
\hline 2 Klebsiella pneumoniae & rabbit nasal exudate & As 163 \\
\hline 3 Klebsiella pneumoniae & mare vaginal discharge & Ex V 129 \\
\hline 4 Klebsiella pneumoniae & cat nasal discharge & Ex N 86 \\
\hline 5 Klebsiella pneumoniae & canine piodermitis & Ex P 183 \\
\hline 6 Klebsiella pneumoniae & canine piodermitis & Ex P 190 \\
\hline 7 Klebsiella pneumoniae & canine piodermitis & Ex P 201 \\
\hline 8 Klebsiella pneumoniae & canine piodermitis & Ex P 204 \\
\hline 9 Klebsiella pneumoniae & canine uroculture & O 47 \\
\hline 10 Klebsiella oxytoca & equine dermal ulcer & U 163 \\
\hline 1 Escherichia coli & canine otitis & Ex O 1056 \\
\hline 2 Escherichia coli & canine otitis & Ex O 1060 \\
\hline 3 Escherichia coli & minced bovine meat & C 441 \\
\hline 4 Escherichia coli & minced bovine meat & C 448 \\
\hline 5 Escherichia coli & equine dermal ulcer & U 162 \\
\hline 6 Escherichia coli & canine nasal discharge & Ex N 91 \\
\hline 7 Escherichia coli & calf faecal swab & MF 21 \\
\hline 8 Escherichia coli & calf faecal swab & MF 28 \\
\hline 9 Escherichia coli & calf faecal swab & MF 29 \\
\hline 10 Escherichia coli & calf faecal swab & MF 30 \\
\hline 11 Escherichia coli & calf faecal swab & MF 31 \\
\hline 12 Escherichia coli & deer liver & As 165 \\
\hline 1 Proteus mirabilis & canine piodermitis & ExP 177 \\
\hline 2 Proteus mirabilis & canine otitis & Ex O 1011 \\
\hline 3 Proteus mirabilis & canine otitis & Ex O 1030 \\
\hline 4 Proteus mirabilis & canine otitis & Ex O 1045 \\
\hline 5 Proteus mirabilis & equine dermal ulcer & U 160 \\
\hline 6 Proteus mirabilis & equine dermal ulcer & U 162 \\
\hline 7 Proteus mirabilis & ant-bear fecal swab & AS 164 \\
\hline
\end{tabular}

44 strains $(63,7 \%)$ were Proteus spp, belonging to $m i-$ rabilis $(\mathrm{n}=33,75 \%)$ and vulgaris $(\mathrm{n}=11,25 \%)$ species, followed by Enterobacter spp $(\mathrm{n}=14,20,3 \%)$, Klebsiella $\operatorname{spp}(\mathrm{n}=7,10,1 \%)$ and Escherichia coli $(\mathrm{n}=6,8,7 \%)$. Other isolates were 38 strains, corresponding 12 to Enterobacter spp., 8 to E. coli and Proteus spp. respectively, 6 to Klebsiella spp. and 4 to Citrobacter spp from $21 \mathrm{pu}-$ rulent exudates, 2 nasal, conjuntival and vaginal swabs each one, 2 faecal cultures and 2 urocultures. As we do not know the resistance of enterobacteriae from water we included those isolated from non-chlorinated water of rural area.

As the serine- $\beta$-lactamases, AmpCs, are induced and occur naturally in Enterobacter spp., C. freundii and $S$. marcescens ${ }^{8,12}$, they were excluded of this study owing their intrinsic antimicrobial resistance (inherent or innate, not acquired) which is reflected in wild type antimicrobial patterns of all or almost all representative species ${ }^{3}$.

Owing that enterobacteria isolated from these pathological process presented resistance to different $\beta$-lactam antibiotics, the aim of the present work was to try phenotypically determined the origin of this, to establish susceptibility patterns of each genre in order to know the best options for treatment. 


\section{MATERIAL AND METHODS}

Thirty seven strains of enterobacteria, 29 from clinical samples (Table 1) and 8 from non-chlorinated water of rural areas of Corrientes Province, at North East of Argentina: E. coli $(\mathrm{n}=5), K$. pneumoniae $(\mathrm{n}=2)$ and $K$. oxytoca $(\mathrm{n}=1)$, were studied for their susceptibility to $\beta$-lactam antibiotics using antibiotic-diffusion on Mueller-Hinton agar by Kirby-Bauer antibiogram ${ }^{3}$.

Antibiotic discs (Britania ${ }^{\circledR}$ ) of ampicillin (Ampi $10 \mu \mathrm{g}$ ), cefotaxime (Cftx $30 \mu \mathrm{g}$ ), cefepime (Fep $30 \mu \mathrm{g}$ ), piperacillin (Pip $100 \mu \mathrm{g}$ ) and with $\beta$-lactam inhibitors: clavulanic acid-amoxicillin (CAM 20/10 $\mu \mathrm{g}$ ), sulbactam-cefoperazone (S-Cfpz 75/30 $\mu \mathrm{g}$ ) and tazobactampiperacillin (TAZ 100/10 $\mu \mathrm{g}$ ) were used. To detect extended spectrum $\beta$-lactamases (ESBL) strains which hidrolyzed $3^{\text {a }}$ generation cephalosporins (Cftx, ceftazidime $\mathrm{Caz} 30 \mu \mathrm{g}$ ) as well as the monobactam aztreonam (Azt $30 \mu \mathrm{g}$ ) and those inhibited by CAM but not by cefoxitin (Fox $30 \mu \mathrm{g}$ ) were observed; boronic acid discs (Bor) were also used because its hability to inhibit plasmidic AmpC serin $\beta$-lactamases (AmpCp) with $3^{\circ}$ generation Cfp as indicators ${ }^{17}$.

The strains were also analysed to phenotypically determine the presence of metallo- $\beta$-lactamase (MBL):

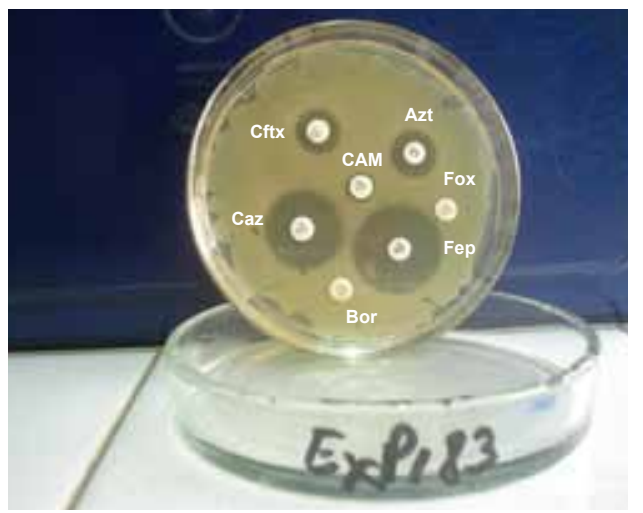

Figure 1. K. oxytoca from canine piodermitis resistant to Cftx, Azt, CAM and Fox.

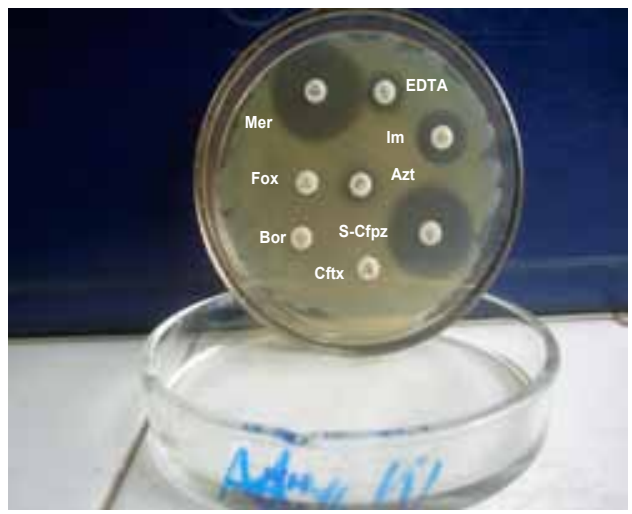

Figure 3. K. pneumonaie from equine adenitis resistant to Im, Fox, Azt and Cftx. monodiscs of the carbapenems imipenem (Im, $10 \mu \mathrm{g}$ ) and meropenem (Mer, $10 \mu \mathrm{g}$ ) with one of ethilendiaminotetraacetic acid (EDTA, $1 \mu \mathrm{mol}$ ) acting as MBL inhibitor were used according the agar diffusion method $^{6}$. The test is positive when there is synergism between EDTA and carbapenem discs.

\section{RESULTS}

All strains of Proteus mirabilis (7/7, 100\%) and 5/16 $(31,2 \%)$ of $E$. coli were resistant to ampicillin. With the aggregate of clavulanic acid to amoxicyllin (CAM) they turned susceptible in 71,4 and 87,5\% respectively.

Four strains of $P$. mirabilis were simultaneously resistant to Ampi and Cftx and susceptible to CAM and S-Cfpz; two strains of K. pneumoniae and one E. coli resistant to Pip were sensible to TAZ. With respect to E. coli, 3/16 were resistant to Ampi and susceptibly to CAM and presented simultaneous resistance to Cftx and Azt. There was not observed enlarged inhibition halo for ESBL phenotypic detection in these strains.

Cefoxitin resistance was present in $K$. pneumoniae (3/11, 27,2\%) and P. mirabilis $(3 / 7,42,8 \%)$ that naturally lack the AmpC gene. Metallo $\beta$-lactamases were not detected in these strains although resistance to imipen-

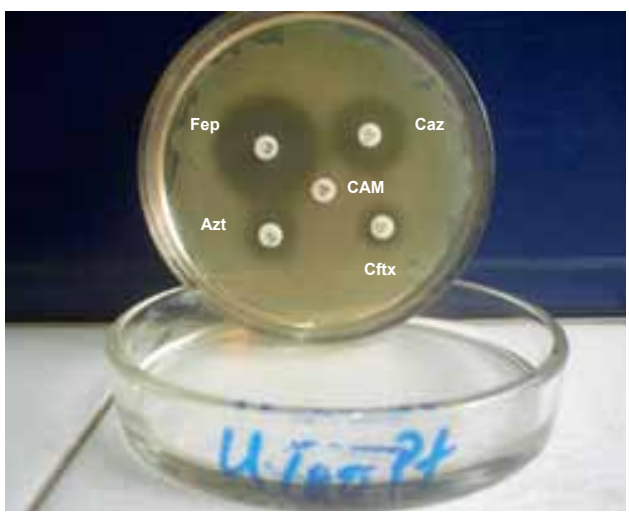

Figure 2. P. mirabilis from equine dermal ulcer resistant to Azt, Cftx and CAM.

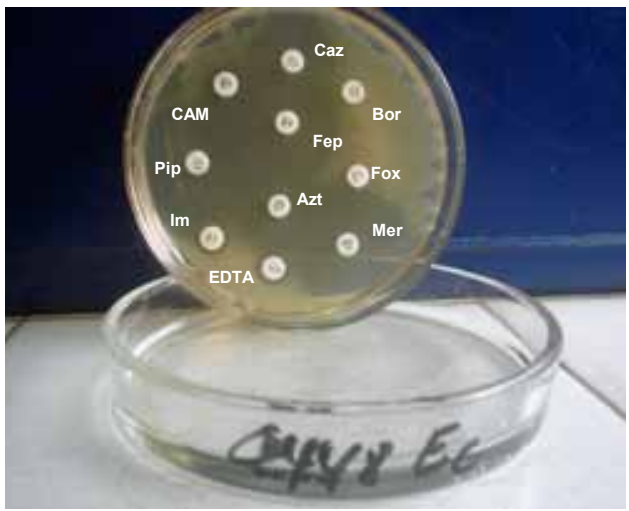

Figure 4. E. coli from bovine minced meat resistant to Im, Fox and CAM and susceptibily to other $\beta$-lactams.

Abbreviations: CAM: clavulanic acid-amoxycillin, Pip: Piperacillin, TAZ: Tazobactam-piperacillin, Ctx: Cefotaxime, Fox: Cefoxitin, Caz: Ceftazidime, Fep: Cefepime, S-Cfpz: Sulbactam-cefoperazone, Im: Imipenem, Mer: Meropenem, Azt: Aztreonam, Bor: Boronic acid, EDTA: Ethilendiaminotetraacetic acid. 
em, was observed in 9 of them: $3 \mathrm{~K}$. pneumoniae, $3 \mathrm{E}$. coli and 3 P. mirabilis, all of animal origin.

\section{DISCUSSION}

Cefoxitin resistance found in this work in bacterias like K. pneumoniae and P. mirabilis that naturally lack the AmpC gene, may be a sign of the presence of plasmidic AmpC of epidemiological importance because its facility to horizontal dissemination. One characteristic of chromosomic type AmpC $\beta$-lactamases is that they have no effect on $4^{\circ}$ generation cephalosporins neither on carbapenems so they are the $\beta$-lactam antibiotic of therapeutic election.

As there was not detected ESBL, it is concluded that the mechanisms of resistance may be produced by means of altered PBP that reduce affinity to $\beta$-lactam antibiotics as well as the synergy between reduced drug intake and active efflux pumps.

As the phenotypic screening was also negative for detecting metallo- $\beta$-lactamases (MBLs) producing isolates, the resistance to imipenem observed in nine strains, was more likely due to a decrease in the expression of an outer membrane protein channel for imipen$\mathrm{em}^{11}$. Owing that MBLs do not efficiently hydrolyze aztreonam, its sensibility would be a good predictor of the enzyme presence in resistant bacteria to imipenem and meropenem ${ }^{5}$. This was not the case in this work, where all the strains susceptible to aztreonam were also susceptibly to meropenem.

We agree with authors that interdisciplinary approaches including human and veterinary experts should be implemented to develop reliable investigation procedures with respect to the current reality of animal owners and their pets ${ }^{18}$. Additionally, consequent basic hygienic measures, prudent use of antimicrobials in companion animals and efforts regarding implementation of antibiotic stewardships should be fostered.

\section{REFERENCES}

1. Amábile-Cuevas CF. 2010 Antibiotic resistance in Mexico: a brief overview of the current status and its causes. $J$ Infect Dev Ctries 4: 126-131.

2. Bush K. 2004. Why it is important to continue antibacterial drug discovery ASM News 70: 282-286.

3. Clinical and Laboratory Standards Institute. 2010. Performance standards for antimicrobial susceptibiliy testing. Twentieth Informational Supplement. CLSI document, Wayne, PA. M100-S20.

4. Diekema DJ. 2008. Drug resistance, http://www.accessscience.com.
5. Gómez S, Rapoport M, Togneri A, Viegas J, Faccone D, Corso A, Petronia A, Pasteran F. 2011. Emergence of metallo- $\beta$-lactamases in Enterobacteriaceae from Argentina. Diagn Microb \& Infect Dis 69: 94-97.

6. Kumar A, Schweizer HP. 2005. Bacterial resistance to antibiotics: Active efflux and reduced uptake. Adv Drug Deliv Rev 57: 1486-1513.

7. Marshall BM, Ochieng DJ, Levy SB. 2009. Commensals: underappreciated reservoir of antibiotic resistance. Microbe 4: 231-238.

8. Martínez Rojas DV. 2009. Betalactamasas tipo AmpC: generalidades y métodos para detección fenotípica. Rev Soc Venez Microb 29: 78-83.

9. Nikaido H. 2003. Molecular basis of bacterial outer membrane permeability revisited. Microbiol Mol Biol Rev 67: 593-656.

10. Paterson DL. 2006. Resistance in Gram-negative bacteria: Enterobacteriaceae. Am J Med 119: 6, S20-S28.

11. Pfeifer Y, Cullick A, White W. 2010 Resistance to cephalosporins and carbapenems in Gram-negative bacterial pathogens. Int J Med Microb 300: 371-379.

12. Polsfuss S, Bloemberg GV, Giger J, Meyer V, Böttger EC, Hombach M. 2011. Practical approach for reliable detection of AmpC beta-lactamase-producing Enterobacteriaceae. J Clin Microb 49: 2798-2803.

13. Poole RK. 2001. Drug efflux pumps, http://www.accessscience.com.

14. Rosas I, Amábile-Cuevas CF, Calva E, Osornio A. 2011. Health implications of animal and human waste as components of urban dust pollution. In: Encyclopedia of Environmental Health (Nriagu J.O. ed.), Elsevier, Amsterdam, $2011 \mathrm{p}$.

15. Schultsz C, Geerlings S. 2012. Plasmid-mediated resistance in Enterobacteriaceae changing landscape and implications for therapy. Drugs 72: 1-16.

16. The American Academy of Microbiology. 2009. Antibiotic resistance: An ecological perspective on an old problem. http://academy.asm.org/images/stories/documents/ antibioticresistance.pdf.

17. Tsakris A, Themeli K, Poulou A, Vrioni G, Voulgari E, Koumaki V, Agodi A, Pournaras S, Sofianou D. 2011. Comparative evaluation of combined-disk tests using different boronic acid compounds for detection of Klebsiella pneumoniae carbapenemase-producing Enterobacteriaceae clinical isolates. J Clin Microb 49: 2804-2809.

18. Wieler LH, Ewers C, Guenther S, Walther B, Lübke AQ. 2011. Methicillin-resistant staphylococci and extended-spectrum beta-lactamases producing Enterobacteriaceae in companion animals. Int J Med Microb 301: 635-641. 